\title{
École et religion, Freedom of Religion and Schools, Cultural Politics and Irish Education
}

\section{Eoin Daly}

\section{(2) OpenEdition \\ 1 Journals}

\section{Electronic version}

URL: http://journals.openedition.org/etudesirlandaises/2499

DOI: 10.4000/etudesirlandaises.2499

ISSN: 2259-8863

\section{Publisher}

Presses universitaires de Caen

\section{Printed version}

Date of publication: 30 December 2011

Number of pages: 173-183

ISSN: 0183-973X

\section{Electronic reference}

Eoin Daly, "École et religion, Freedom of Religion and Schools, Cultural Politics and Irish Education ». Études irlandaises [Online], 36-2 | 2011, Online since 30 September 2011, connection on 21 September 2020. URL : http://journals.openedition.org/etudesirlandaises/2499; DOI : https://doi.org/10.4000/ etudesirlandaises. 2499

This text was automatically generated on 21 September 2020 .

\section{(c) (i) (9)}

Études irlandaises est mise à disposition selon les termes de la Licence Creative Commons Attribution - Pas d'Utilisation Commerciale - Partage dans les Mêmes Conditions 4.0 International. 


\title{
École et religion, Freedom of Religion and Schools, Cultural Politics and Irish Education
}

\author{
Eoin Daly
}

\section{REFERENCES}

Karin Fischer, École et religion: Hiérarchies identitaires et égalité citoyenne en République d'Irlande, Caen, Presses Universitaires de Caen, 2011, ISBN : 978-2-84133-376-9, €24 Alison Mawhinney, Freedom of Religion and Schools : The Case of Ireland, Saarbrücken, VDM, 2009, ISBN 978-3-63914-102-3, £59

Denis O'Sullivan, Cultural Politics and Irish Education since the 1950s: Policy, Paradigms and Power, Dublin, Institute of Public Administration, 2005, ISBN 978-1-9045-4126-4, €45

Little illustrates the conflicting narratives of constitutional identity in the Republic of Ireland better than the evolving relationship of religion and public education. Since the $19^{\text {th }}$ century, public education in the Republic has been devolved along denominational lines, partly as a product of resistance to the imposition of British state education. Rather than providing public education directly, the independent State has historically "provided for" free education at primary and secondary levels by recognising and funding schools under the ownership and management of religious denominations. Thus, even today, more than $90 \%$ of "national" primary schools in the Republic are operated according to a Roman Catholic ethos, the consequence of this being, for families in many areas of the State, that there may effectively be little choice but to attend a school committed to the inculcation of Catholic beliefs - notwithstanding the explicit constitutional right to withdraw from formally-timetabled religious instruction classes $^{1}$. Yet the paradox of this state of affairs lies in the fact that formally and constitutionally, the Republic of Ireland is a non-sectarian state; religious discrimination and the "endowment" of religion are prohibited in the 1937 Constitution, ${ }^{2}$ and the democratic principle of freedom of parental choice in matters of 
religious education, although riven with ambiguity, is consensually regarded as the cardinal constitutional precept. Thus, while the public education system is overwhelmingly confessional in reality, the State is formally neutral towards religion, and any State support for confessional education is legitimated only by the idea that this supports the "choice" of parents - however this might be ascertained - rather than on the basis of any intrinsic good attributed to religion itself. Indeed, the historic denominational model relies on a somewhat optimistic and crude conjecture - that the educational and religious freedom of the citizens can be safeguarded by devolving the public education function to private intermediaries that can give specific expression and recognition to the determinate religious identities in society - in preference to what is sometimes derided as a "one size fits all" model of unitary, secular public education ${ }^{3}$. In any case, the contradicting justifications for the denominational model one, as a recognition and protection of a specifically religious Irish identity, and another, centring on the secular goods of "diversity" and "choice" - mirrors the broader, competing duality of narratives of Irish public identity, Christian and republican - best encapsulated, perhaps, in the constitutional affirmation that "all powers of government [...] derive, under God, from the people"4.

2 Three recent books explore the problematic position of religion in Irish education from very different disciplinary standpoints and methodological approaches, with each casting different light on the broader significance of this question in national and constitutional identity. In Freedom of Religion and Schools: the Case of Ireland, Alison Mawhinney considers, from a jurist's perspective, the implications of the heavily denominational system for the human rights of parents and children with respect to such issues as subjection to involuntary religious instruction and influences within schools, and the implementation of the constitutional right to withdraw from religion classes in publicly-funded schools. She focuses primarily on the legal rights guaranteed in international instruments to which Ireland is signatory, such as the European Convention on Human Rights. In a broader ideological and cultural lens, Denis O'Sullivan's book focuses on the relative weakening of religious influence on broader education policy. In Cultural Politics and Irish Education since the 1950s: Policy, Paradigms and Power, he argues that the overriding paradigm in education policy has shifted from a "theocratic" to a "mercantile", neo-liberal premise between the mid and late twentieth century. Most recently, in École et religion: Hiérarchies identitaires et égalité citoyenne en République d'Irlande, Karin Fischer also considers both the historical and ideological context of the Republic's highly confessional public education system. She focuses both on its positioning within the broader, ambiguous relationship between religion and national identity, as well as its recent evolution in the lens of demographic and sociological change.

3 Fischer in particular shows an impressive command of the normative backdrop to the heavily denominational - although formally pluralist model - forged under British sovereignty in the $19^{\text {th }}$ century, and of which the essential features remain intact today, notwithstanding the ostensibly more pluralist and secular tenor of public discourse. She is explicit in her description of the public education system, "characterised as confessional and founded on religious segregation [...] experienced by some as a form of cultural imperialism ${ }^{5}$. Similarly, Mawhinney, in her recent book and broader work, offers a jurist's perspective on the effect, on children's and parents' fundamental rights, of the "integrated curriculum" policy in Irish schools, under which the religious 
"ethos" is incorporated within all aspects of the school environment. Her empirical study suggests non-coreligionists as minorities are poorly accommodated despite certain constitutional guarantees, sometimes amounting to pressures to effectively participate in religious exercise, for the sake of maintaining Catholic schools' "ethos". She conducted surveys of and questionnaires with parents and children affected by various aspects of the denominational model, and used these findings as a measure of the compatibility of the broader education model with the standards found in international human rights law. In particular, she focuses on the difficulties faced by parents in educating their children free from unwanted religious influences, along with the pressure to remain observant Catholics in order to guarantee their children's admission to schools ${ }^{6}$.

4 Moreover, in a broader lens, Fischer conveys a sensitive and nuanced awareness of the competing narratives of Irish nationalism that underpin the somewhat contradictory rhetorical and constitutional buttresses of the denominational system. The romanticnationalist narrative, ascendant in postrevolutionary Ireland, posits an essentially religious, Christian, and perhaps even Catholic conception of national identity - a conception which represented the legitimation of the denominational model in the early independent state, approximating to what Fischer terms a "triumphalist" Catholic nationalism ${ }^{7}$. Fischer explains the essentially post-colonial phemonenon of a reliance of public education as an instrument for cementing national identity in the nascent, post-independence state ${ }^{8}$ - while recognising the historical opposition of certain revolutionary nationalist figures to clerical control over education. ${ }^{9}$ She perceptively documents how while the hybrid public-private structure of national education was unchanged upon independence, its function changed - to that of the reproduction and assertion of the "Gaelic-Catholic" character of the Irish ethnos, in order to "secure the legitimacy of the state ${ }^{10}$ ". Yet the emphasis was primarily on Gaelic cultural identity, with the new state resisting a full-blown sectarian-Catholic definition of the polity ${ }^{11}$. Ostensibly secular instruction was informed by a conception of religion as salient in Irish identity and history. Indeed, this is echoed in O'Sullivan's description of the "theocratic" paradigm that dominated educational policy in the early decades of independence. Then, he writes, "the aim of education [...] [was] to be determined by unchanging principles based on a Christian view of human nature and destiny ${ }^{12}$ ".

Consequently, the policy of "integrating" religious ethos within the whole school curriculum, formally adopted in 1965, threatened to undermine the freedom of conscience of non-coreligionists ${ }^{13}$. While the explicit religious basis of national education has disappeared from official documentation, particularly since the revised primary curriculum in $1999^{14}$, Fischer documents a residual, latent assumption of a common Christian heritage and identity, although the formal structure of national education, with its distinct "patronage" model, is officially neutral towards citizens' comprehensive worldviews. All of this has taken place against a vaguely antiideological leaning in curricular matters, according to which the Christian and Gaelic basis of Irish identity is seen as self-evident, and to go without saying ${ }^{15}$. Indeed, the main contribution of the empirical research in Mawhinney's recent book is to demonstrate how, notwithstanding the relative weakening of the religious dimension of the curriculum at the official level, the threat posed by the confessional system, to the rights of non-coreligionists, very much remains. Parallel to this, O'Sullivan documents how the essential structure of the denominational model now co-exists with a very different background ideological motivation in education policy, a very different 
conception, secularised and quasi-utilitarian, of the self and its ends, and its relationship to the national community - hence "a transition from an institution that had God at its centre to one in which 'trade/exchange' is at its core". He notes: "in contrast to [the earlier] dogmatic prescriptiveness about the purpose of education, the mercantile paradigm assumes a populist approach holding that what education is for is a matter for consumers of the system ${ }^{16}$."

6 Fischer also acknowledges the competing, alternative tradition of secular, republican nationalism - originating with the Jacobin-influenced revolutionaries of the $18^{\text {th }}$ century - which resists any sectarian definition of national identity, and is somewhat resonant, as she points out, with the universalist tendencies of the ideal of national identity in French republicanism, as expressed by Ernest Renan - as resting on vouloir vivre ensemble alone - the solely political terms of the republican social contract rather than the pre-political commonalities of ethnicity and religious affiliation. Fischer intelligently acknowledges how the formal pluralism of the denominational model - no constitutional privilege is accorded to Catholic or Christian schools allowed for an implicit reconciliation with the republican mores that has constituted a competing narrative of Irish nationalism, more civic and inclusive. Indeed, in a broader lens, both the political soul-searching that followed upon the recent economic collapse, and the reaction to spate of recent public reports on clerical child abuse, have fuelled the emergence of a secularised leitmotif of anti-sectarian republicanism, redolent of the United Irishmen, which re-asserts the non-sectarian tenor of national identity and the dissociation of civil and religious authority. This was evident, for example, in the Taoiseach Enda Kenny's remarkable recent speech to the Dáil, in reaction to the Cloyne report on child abuse, where he castigated the "dysfunction, disconnection, elitism, the narcissism" dominating the Vatican and asserted the idea of a "Republic of laws" in which the Church would receive no privileged institutional status ${ }^{17}$. It is clear that the centrality of religion to national identity has clearly dissipated at both social and institutional levels, yet as Fischer points out, while reference to the essential importance of religion per se has disappeared from policy documents, it continues to be latent in the very conception and structure of the denominational system. ${ }^{18}$ In discourse and policy, the Catholic Church has been de-nativised, and its legitimacy, as an educational provider on a juridical par with other bodies, is increasingly accepted as resting contingently on its capacity to still represent parental "choice" (however this might be ascertained). Yet this formally pluralist stance, asserting a privatisation of religion, is incongruous with a continuing de facto hegemony of the majority Church in the control and management of the "national" schools. Given the secularisation of Irish society, there is an internal contradiction in the constitutional logic of the current framework: if the position of the Church(es) is underpinned, in normative terms, by the "natural" and "antecedent" rights of parents exalted in the Constitution - and if this is interpreted as according parents a power to determine the "ethos" of the national schools - then the system as it stands has had the metaphorical rug pulled from underneath it. The current discourse may be interpreted as an effort at the recalibration of the "choice" - oriented legitimation for a secularised society. Yet O'Sullivan points to the paradox latent within this stance, noting: "[...] if the purpose of education is to lead people to God and to facilitate them in teaching their eternal salvation, it follows that the designated religious authorities - church, religious personnel - can claim privilege in relation to the ownership, management and general control of schools. On the other hand, if consumers are entitled to decide what 
education is for they must also be facilitated in establishing schools, through individual or collective initiative, according to their philosophy of life, if the existing school system is unresponsive to their demands ${ }^{19}$."

7 Indeed, it seems unlikely that any nascent resurgence of civic republicanism might provide a third, alternative narrative for national educational policy, supplanting both the "theocratic" and the neo-liberal, "mercantile" paradigms. If there is a resurgence of secular republicanism in the southern polity, it has not given rise to any serious discussion on the possible establishment of a truly "national", non-sectarian public education system, administered by local authorities along the lines of Ireland's European neighbours. The Minister for Education, Ruairi Quinn - whom while in opposition, suggested the Department he now controls was infiltrated by "obscurantists ${ }^{20 "}$ - has applied pressure on the religious congregations whom the State indemnified against liability for child abuse claims in 2002 to divest patronage and ownership of some of their publicly-funded schools to the control of the State. However, the terms of the reform debate have not been framed with a view towards the universal provision of non-sectarian public education across the State, as a matter of right, so as to ensure liberty of conscience for individuals irrespective of the social and demographic clout of their group - in such a manner as might deal with the main problems with the denominational model documented in Mawhinney's empirical contribution. Instead, it has focused on the more limited horizon of "diversifying" the provision of different models of religious and non-religious education within the current structure and rationale of the "historical" patronage model, in which the State will continue to devolve its educational responsibilities to private agents, albeit with a greater "choice", for educational consumers, between different types of school "ethos". Thus, the recent focus on "choice" in education does not represent any real departure from the "mercantile" premise identified in O'Sullivan's book, in the sense that it is predicated more on the educational consumer than on any concept of equal citizenship. Whereas the historical model failed to cater for the liberty of conscience of minority and non-religious citizens, the current debate has, despairingly, focused merely on the re-adjustment of that model so as to account for recent social change - but will thus continue to leave the guarantee of citizens' liberty of conscience vulnerable to such arbitrary contingencies as whether parents holding particular beliefs are sufficiently numerous to attract State recognition for a school specifically attuned to those beliefs. Explicit support for a completely non-sectarian system of national education has, Fischer notes, been found only in the pronouncement of the obscure "Far Left" parties $^{21}$. The return of the secular-leaning Labour party as a powerful influence in Government in 2011 has not led to any meaningful interrogation of the very structure and conception of national education, but merely to proposals for certain accommodations and adjustments within its existing conceptual contours. Yet the Catholic Church, weakened by the abuse scandals, has declared itself ready to divest control of at least some of "its" schools to secular control, being forced to revise its historical claims to privileged influence and deference in the public sphere within the more democratic and secular terms of pluralism and "choice". Yet again, this exposes a potential paradox, in the Church's acceptance that the only democratic basis for the legitimacy of its position in the national education system lies in its claim to represent and express the legitimate educational choices of parents, rather than in any intrinsic status it enjoys. This ambitiously and simplistically presupposes that the preferences and choices even of Catholic parents, as an imagined unitary bloc, can be represented 
by and entrusted to the institution of the Church - absent any mechanism for ascertaining actual parental "choice". O'Sullivan's book alludes to this paradox where he refers to the "presumption of the Roman Catholic Church [in] speak[ing] authoritatively, and not merely representatively, in this regard for Roman Catholic parents ${ }^{22}$."

In a broader lens, Fischer illustrates how the shift away from an exclusionary national identity based on religion has been substituted by an alternative, communautariste politics of identity, which seeks to accommodate the reasonable pluralism of citizens' beliefs through a process of group recognition, rather than the assertion of a common civic identity that abstracts from citizens' various supra-political identities. "Diversity" is reductively conceived within the framework of discrete "communities" as if to imagine that Ireland were perfectly homogenous and monocultural prior to its recent experience of immigration. Moreover, Fischer's book conveys an understanding of the deficiencies of this group-oriented approach to the accommodation of religious and cultural difference - because the strategy of providing State recognition and funding for schools specifically catering to discrete religious minorities may overlook certain individuals, and distribute liberty of conscience unequally, as a function of the relative size and political capital of those groups ${ }^{23}$. Although the State funds the schools of different religions and cultures on a basis of formal equality, more peripheral groups will struggle to successfully negotiate the processes of school recognition; therefore, the full measure of educational freedom hinges on the demographic clout of one's "group". Thus, Fischer argues that the discourse and structure of national education in the Republic implicitly exalts the cultural rights of religious groups in preference to the equal basic liberties of individual citizens; indeed, the educational freedom of children - to not be subject to religious indoctrination contrary to their freedom of conscience is routinely overlooked and merely subsumed with the rights of parents. Children's independent citizenship is not taken very seriously; rather, they are unthoughtfully corralled within predetermined religious identities ${ }^{24}$. The State's role is reduced to the impartial administration of the educational prerogatives of sectional groups; the Fianna Fáil governments of the 2000s, in particular, conceived the State as a guarantor of the interests of discrete communities and particularisms, rather than of the equal basic liberties of parents and children as citizens. Indeed, this points to a disparity between O'Sullivan's and Fischer's books, in the relative emphasis they place on the role of disenchanted, secular, market-driven ideology in the case of the former, but on the residual role for politics of identity and culture, in education, for the latter - even if this takes the form of a sectoral, communitarian analysis, rather than the narrower nationalism of the past.

9 What is most praiseworthy in Fischer's work in particular is her effort to illustrate how the constitutional and policy framework for religion and education in the Republic expresses and straddles these competing traditions of constitutional and national identity, Christian and republican, in modern Ireland. Put differently, the main merit of this book lies in its treatment of the denominational model in the light of the background philosophical and political oscillation between civic republicanism and ethnic nationalism in modern Ireland. In particular, while displaying an impressive command of the administrative, policy and historical basis of the national education system, Fischer gives a sensitive treatment of the challenges posed to the denominational model by the unprecedented migration and consequent cultural diversity experienced in the "Celtic Tiger" years of the 1990s and 2000s. This saw 
certain policy moves towards "inter-culturalist" stances and accommodation of cultural differences, yet also, a defensive tendency towards the retrenchment of the Catholic identity of the "national" schools. In particular, the spectre of large-scale educational segregation - along class and racial, as well as religious lines - has loomed, in tandem with broad recourse by denominational schools to their statutory right to discriminate, on religious grounds, in enrolment. At one point, in 2007, the State was forced to open an "emergency" school catering almost exclusively for children of migrant origin, who could not access any publicly-funded Catholic schools as they did not possess the necessary Catholic baptismal certificate. Anecdotally, some of those excluded migrants were apparently informed by schools : "we look after our own first ${ }^{25}$ " illustrating the intersection of the ostensibly religious dimensions of the problem with the demarcation and hierarchisation of other identities in the Irish polity - national, ethnic and racial. Fischer notes the defensive Catholic reaction to diversity, based on both a reassertion of the "ethos" of schools, and an insistence on their essentially inclusive nature ${ }^{26}$. This analysis of the background politics of national identity influencing discourses on religion and education offers a welcome context to the human rights concerns detailed in Mawhinney's recent book.

10 As O'Sullivan's book highlights, the issue of religion and education in the Republic must be viewed against the broader conception of the educational consumer in Irish discourse - although this can only account in part for the curious moral value attributed, in the recent debate, to the aggregate preferences of groups of citizens seeking provision of a certain type of school model. Certainly, the greater "diversity" of the Irish population does not, in principle, by itself provide sufficient moral reason for reforming the denominational model : there was never an imaginary past era of nearperfect religious homogeneity in Irish society which would have rendered it acceptable to devolve the public education function to a near-monopoly of denominational provision. Yet while immigration does not in itself alter the qualitative parameters of the question, in the realpolitik of educational policy, greater religious diversity has placed the denominational model under administrative strain and intense public scrutiny - although unfortunately, this has not translated as a deeper critique of the formal pluralism of the patronage model that is currently the subject of reform efforts. As Fischer points out, much of the literature and discourse centres on how the education system should be reformed so as to reflect the contingent, de facto demographic and religious landscape of Irish society, rather than on what is required by the equal citizenship of parents and children, independently of the evolving communal landscape ${ }^{27}$. Beyond the issue of how equal liberty of conscience can be assured within the structure of national education, the author notes how the national school environment serves as a microcosm of conceptions of citizenship and as a tool for the reproduction of identities 28 ; thus, the debate on the choice of school model refracts competing views of citizenship based either on the republican conception of a common civic identity, or the "mosaic" of discrete communitarian identities.

11 As Fischer acknowledges, the ongoing public debate on religion and education in the Republic echoes challenges and conflicts experienced in every democratic society how may the State assume its educational responsibilities while respecting citizens' liberty of conscience? While Mawhinney brings a jurist's perspective to the human rights implications of this problem, Fischer's contribution is to document how it also refracts broader issues of national identity and social change in contemporary Irish society. She skilfully explores the social and ideological implications of the position 
accorded to religion in Irish schools, yet also appreciates its refraction in broader government stances and normative debates. Fischer charts the evolving ideological legitimation of the Republic's reliance on and support for denominational schools, from the nativist Gaelic nationalism of the early State - which retains some contemporary residue - to the present-day hesistant re-assertion of the "republican ideal", although compounded with a vague sense of commununitarian recognition, under the influence, no doubt, of the identity politics of the Anglophone sphere. It is possible that her emphasis on the continuing influence of "religious ethno-nationalism" in framing the discourse on schools may under-play the emergence of a secularised, vaguely neoliberal politics of school "choice", which legitimates the "patronage" model in promoting the idea that it positively accounts for prevailing parental preference and offers a diversity of school models, empowering the educational consumer rather than promoting a republican view of the common good. This perspective is amply covered, albeit from a different angle, by O'Sullivan's book - which was published before the most recent controversies on denominational schools - with its focus on market ideology in educational discourse and policy. Nonetheless, áine Hyland offers no exaggeration in remarking, in the preface, that Irish scholarship owes Fischer a debt of gratitude for her book. Her timely contribution - one of the most authoritative recent books on this area, in any language - most notably conveys an impressive mastery of Ireland's historical, political and social landscape, and a thorough familiarity with the politics and sociology of education in the Republic.

\section{NOTES}

1. See generally A. Mawhinney, Freedom of Religion and Schools: the Case of Ireland, Saarbrücken, VDM, 2009.

\section{2. . Article 44.2.}

3. . See generally E. Daly, "Religious Freedom as a Function of Power Relations : Dubious Claims on Pluralism in the Denominational Schools Debate", Irish Educational Studies, vol. 28, 2009, p. 235.

4. . Article 6 .

5. . École et religion, p. 17.

6. . A. Mawhinney, "Freedom of religion in the Irish primary school system : a failure to protect human rights?", supra note 7, and "The Opt-out Clause : Imperfect Protection for the Right to Freedom of Religion in Schools", Education Law Journal, vol. 2, 2006, p. 27.

7. . École et religion, p. 34.

8. . École et religion, p. 17-18.

9. . École et religion, p. 37.

10. . École et religion, p. 51. 
11. École et religion, p. 53.

12. Cultural Politics and Irish Education, p. 112.

13. . École et religion, p. 56.

14. . Primary School Curriculum, Dublin, Department of Education and Science, 1999.

15. . École et religion, Chapter III.

16. . Cultural Politics and Irish Education, pp. 104, 112.

17. . P. Cullen, "Vatican Relationship at New Low", The Irish Times, July 21, 2011.

18. . École et religion, p. 19.

19. Cultural Politics and Irish Education, p. 113.

20. . "Either officials in your department are members of secret societies such as the Knights of Columbanus and Opus Dei and they have taken it upon themselves to protect the interests of the clerical orders" or "you [the Minister for Education] are politically incompetent and incapable of managing the department of education". Dáil Eireann, June 11, 2009.

21. . École et religion, p. 197.

22. . Cultural Politics and Irish Education, p. 114.

23. . Daly, "Religious Freedom as a Function of Power Relations".

24. . École et religion, p. 241.

25. . H. McDonald, "Ireland forced to open immigrant school", The Guardian, September 25, 2007, and R. Boland, "Faith before Fairness", The Irish Times, September 8, 2007.

26. . École et religion, p. 22

27. . École et religion, p. 26.

28. . École et religion, p. 243.

\section{AUTHORS}

EOIN DALY

Dublin City University 